in vivo $36: 336-340(2022)$

doi:10.21873/invivo.12707

\title{
Prognostic Significance of p16 Protein Expression in Breast Cancer
}

\author{
MAGDI M. SALIH ${ }^{1}$, AMJED A. HIGGO ${ }^{2}$ and EMAD M. EED ${ }^{1}$ \\ ${ }^{1}$ Department of Clinical Laboratory Science, College of Applied Medical Sciences, \\ Taif University, Taif, Kingdom of Saudi Arabia; \\ ${ }^{2}$ Faculty of Medical Laboratory Science, Histopathology Department, \\ Al Neelain University, Coralville, IA, U.S.A.
}

\begin{abstract}
Background/Aim: Breast cancer is the most common cancer in Sudan. The p16 protein plays a vital role in the regulation of the cell cycle. Patients and Methods: This study analysed the protein expression of p16 in 202 paraffin blocks from Sudanese women with breast cancer using immunohistochemistry. Results: This study included 168 (83.2\%), 16 (7.9\%), and 18 (8.9\%) patients with invasive ductal carcinoma, invasive lobular carcinoma, and papillary carcinoma, respectively. There were 95 cases $(47.0 \%)$ with grade III, 70 cases (34.6\%) with grade II, and 23 cases $(11.4 \%)$ with grade I breast cancer. The hormone receptor status was available for 119 of the cases, and 31 (15.3\%), 25 (12.4\%), and $63(31.2 \%)$ cases were positive for oestrogen, progesterone, and HER2 receptors, respectively. Conclusion: p16 protein expression was associated with high histologic grade, lymph node metastasis, and poor prognosis. p16 protein expression may potentially be used as a prognostic marker.
\end{abstract}

Breast cancer is one of the most common causes of cancerassociated death among women worldwide, and most of the death rates are rising in underdeveloped countries $(1,2)$. Breast cancer is the most common cancer in Sudan with an incidence rate of 25.1 per 100,000 people (3). For patients identified with breast cancer and distant metastasis, management is usually aimed at improving survival (4). Alterations in breast cancer susceptibility genes $B R C A l$ and $B R C A 2$ (5), sex-steroid hormones, and way-of-life origins

This article is freely accessible online.

Correspondence to: Magdi Mansour Salih, Department of Clinical Laboratory Science, College of Applied Medical Sciences, Taif University, P.O. Box 11099, Taif 21944, Kingdom of Saudi Arabia. Tel: +966 543361599, e-mail: Magdi-206@ hotmail.com

Key Words: Sudanese women, breast cancer, p16 protein expression. have been strongly associated with the development of breast cancer, but the mechanisms of breast carcinogenesis are still not clearly understood.

Deregulation of the cell cycle is an important feature of cancer. One of the proteins involved in the cell cycle is p16 (6). p16 oncoprotein is consistently expressed in cancer and can inactivate the retinoblastoma $(\mathrm{Rb})$ tumour suppressor (7). p16 acts as a tumour suppressor, limiting cell proliferation. Changes in p16 can lead to down-regulation of genes, which may increase the incidence of epithelial cell cancer $(8,9)$.

Previous studies have shown that the expression of $\mathrm{p} 16$ correlates with clinicopathological factors in breast cancer (10). Some report a weak association between immunohistochemical expression of p16 and invasive ductal breast cancer, but another study reported that it is the main mechanism of cell-cycle deregulation in invasive breast cancer (11). The aim of this study was to analyse p16 protein expression among Sudanese women with breast cancer using immunohistochemistry.

\section{Patients and Methods}

Breast cancer patient population and sample collection. Paraffin wax blocks were selected from patients that were previously diagnosed with breast neoplasia at the Radiation and Isotopes Centre Khartoum (RICK) in Khartoum State, Republic of Sudan, from May 2017 to June 2018. Clinicopathological data of the patients were collected from the records of RICK. A total of 202 breast cancer patients $(n=202)$, aged 18-85 years, were recruited for analysis of p16 protein expression. The study received ethical approval from the ethical committees of the Faculty of Laboratory Sciences, Al Neelain University.

Immunohistochemical reaction. From each tissue block, two 4- $\mu$ mthick sections were cut and mounted on two microscope slides: one coated with amino-propyl triethoxysilane for immunohistochemistry analysis and the other coated in routinely used adhesive media. All sections were incubated in an oven at $60^{\circ} \mathrm{C}$ for one hour, and then sections were de-waxed with xylene and hydrated through descending alcohol $(100 \%, 90 \%, 70 \%$, and 50\% ethanol and distilled water). To confirm the diagnosis, one section from each 
case was stained with haematoxylin and eosin as described by Fischer et al. (12).

For immunohistochemical staining of p16, slides were incubated overnight at $4^{\circ} \mathrm{C}$ with p16 primary antibody (Santa Cruz Biotechnology, Inc., Santa Cruz, CA, USA) diluted at 1:400. After primary antibody exposure, the slides were washed and treated with biotinylated antibody for $30 \mathrm{~min}$. Antigen visualization was achieved using ENVISION FLEX (DAKO, Carpinteria, CA, USA) for $30 \mathrm{~min}$, followed by diaminobenzidine chromogen (DAKO Liquid DAB+, K3468). Slides were counter-stained with haematoxylin. Finally, sections were dehydrated in alcohol, cleared in xylene, and mounted in Distyrene, a Plasticizer, and Xylene (D.P.X.). All sections were stained in the same batch to eliminate inter-batch variation.

A negative control was prepared from the same tissue block but incubated in phosphate buffer solution instead of the primary antibody. The positive control section for p16 immunohistochemistry was cervical squamous cell carcinoma, which has high p16 expression. The analysis was performed according to the novel recommendations of the College of American Pathologists (CAP) for Human papilloma virus analysis in head and neck carcinomas used in routine clinical practice (13). The p16 immunohistochemistry results were interpreted as follows: high 16 expression: tumours with $\geq 70 \%$ nuclear and cytoplasmic staining; moderate p16 expression: tumours with $30-70 \%$ nuclear and cytoplasmic staining; low p16 expression: tumours with 10$30 \%$ nuclear and cytoplasmic staining, which is considered as abnormal positive p16 expression; and p16 negative: tumours with $1-10 \%$ nuclear and cytoplasmic staining, considered as normal negative p16 expression.

Statistical analyses. Statistical analyses were carried out using the Statistical Package for Social Sciences (SPSS) version 21 (SPSS Inc. IBM, IL USA, 2012). Qualitative variables such as positive p16 expression and clinicopathological features of the patients were expressed as frequencies and percentages. The correlation between p16 expression of breast carcinomas and clinicopathological features was analysed using a chi-squared test $\left(\chi^{2}\right)$. A $p$-value $<0.05$ was considered significant.

\section{Results}

Study group. This study included 202 female breast-cancer cases, including 168 (83.2\%), 16 (7.9\%), and $18(8.9 \%)$ patients with invasive ductal carcinoma, invasive lobular carcinoma, and papillary carcinoma, respectively. There were 95 cases $(47.0 \%)$ with grade III breast cancer, 70 cases $(34.6 \%)$ with grade II, and 23 cases (11.4\%) with grade I. Axillary lymph node metastasis was presented in $57(28.2 \%)$ cases. The hormone receptor status was available for 119 of the cases, and 31 (15.3\%), 25 (12.4\%), and $63(31.2 \%)$ patients were positive for oestrogen, progesterone, and HER2 receptors, respectively. Of the 202 samples, $63(31.2 \%)$ were positive for $\mathrm{p} 16$. The mean age and standard deviation (SD) of the patients was $48.14 \pm 14.4$ years with a range of 18 to 85 years. The clinicopathological characteristics of the study group are summarized in Table I.
Table I. Clinical, pathological and geographical features of breast cancer patients.

\begin{tabular}{lc}
\hline Characteristics & BC $(\mathrm{n}=202)$ \\
\hline Age (mean \pm SD) & $48.14( \pm 14.4)$ \\
$\leq 45 \mathrm{n}(\%)$ years & $101(50.0)$ \\
$\geq 46 \mathrm{n}(\%)$ years & $101(50.0)$ \\
Histologic type, $\mathrm{n}(\%)$ & \\
Invasive ductal carcinoma & $168(83.2)$ \\
Invasive lobular carcinoma & $16(7.9)$ \\
Papillary carcinoma & $18(8.9)$ \\
p16 immunohistochemistry $\mathrm{n}(\%)$ & $63(31.2)$ \\
p16 positive N $(\%)$ & \\
Histological grade $\mathrm{n}(\%)$ & $10(4.9)$ \\
0 & $23(11.4)$ \\
I & $70(34.6)$ \\
II & $95(47.0)$ \\
III & $4(2.1)$ \\
Missing & $57(28.2)$ \\
Lymph node metastasis $(+), \mathrm{n}(\%)$ & \\
Hormone receptors & $96(47.5)$ \\
Oestrogen receptor $(+), \mathrm{n}(\%)$ & $71(35.1)$ \\
Progesterone receptor $(+), \mathrm{n}(\%)$ & $41(20.3)$ \\
Her2 status $(+), \mathrm{n}(\%)$ & \\
\hline
\end{tabular}

p16 immunohistochemistry. In regard to p16 immunohistochemistry results, negative expression was found in $139(68.8 \%)$ cases, while 63 (31.2\%) cases showed moderate and marked nuclear immune reactivity (Figure 1). p16 expression was statistically associated with worse clinicopathological characteristics, such as high histologic grade $(p=0.011)$ and lymph node metastasis $(p=0.003)$. No association was found between p16 expression and breast cancer types, different hormone receptors, and patient age groups $(p=0.436,0.375,0.185,0.323$ and 0.693 , respectively; Table II and Table III).

\section{Discussion}

There is limited information on the efficacy and prognostic significance of p16 in breast cancer. The significance of p16 expression has been recognized in a variety of human cancers but has not been well studied in breast cancer. To the best of our knowledge, this is the first study to offer extensive clinical data on p16 expression in breast cancer among Sudanese women.

p16 is a cell cycle regulator that blocks the action of cyclindependent kinases, which inhibit the retinoblastoma gene $(R B)$. The $R B$ gene guides the progression of the cell cycle from the G1 phase to the $\mathrm{S}$ phase. Changes in the p16 gene and its expression have been investigated in many cancers (14).

The assessment of p16 expression in breast cancer in this study showed a negative reaction in 139 (68.8) cases, while $63(31.2 \%)$ cases showed moderate and marked nuclear immunoreactivity. Previous immunohistochemistry studies 


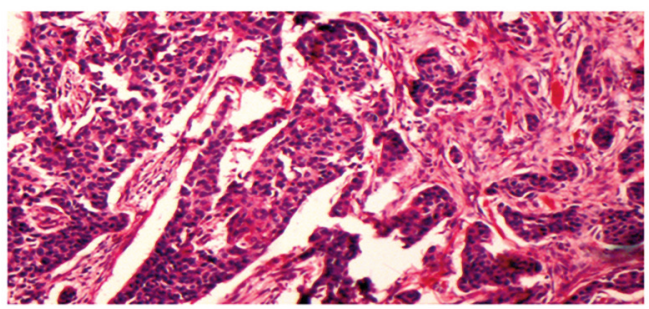

A
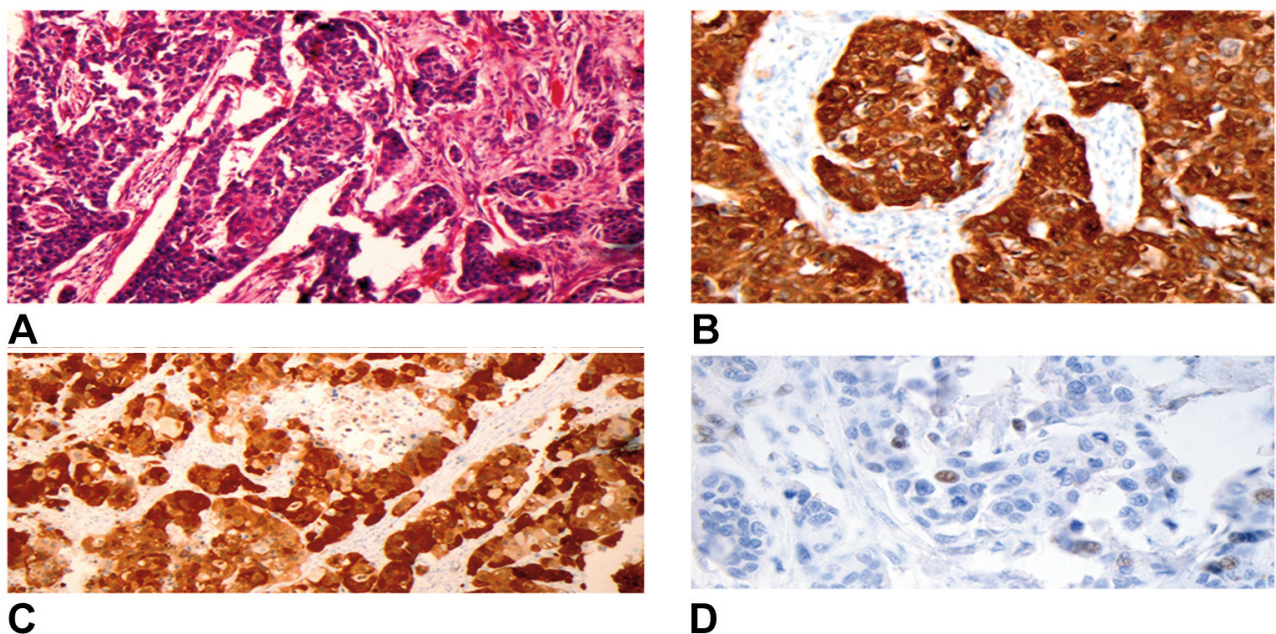

B

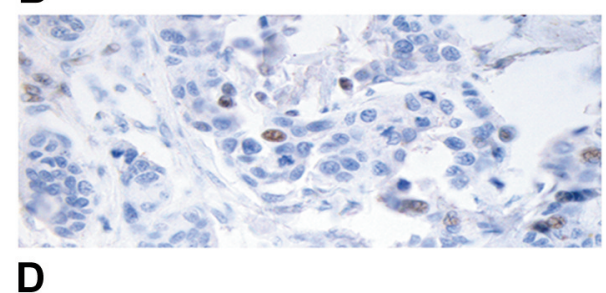

Figure 1. Microscopical images showing p16 immunohistochemical expression. (A) Hematoxylin and eosin-stained section of invasive ductal breast cancer. (B) Immunohistochemical staining for high p16 expression. (C) Positive control of immunohistochemical staining for p16. (D) Negative control of immunohistochemical staining for p16.

Table II. Immunohistochemical expression of p16, cancer types, lymph node metastasis and hormone receptors.

\begin{tabular}{lccc}
\hline & $\mathrm{p} 16+$ & $\mathrm{p} 16-$ & $p$-Value \\
\hline $\begin{array}{l}\text { Invasive ductal } \\
\text { carcinoma N (\%) }\end{array}$ & $53(31.5)$ & $115(68.5)$ & 0.436 \\
$\begin{array}{l}\text { Invasive lobular } \\
\text { carcinoma N (\%) }\end{array}$ & $3(18.8)$ & $13(81.2)$ & \\
Papillary carcinoma N (\%) & $7(38.9)$ & $11(61.1)$ & \\
LN+ N (\%) & $26(41.2)$ & $31(22.3)$ & 0.003 \\
LN- N (\%) & $37(58.8)$ & $108(77.7)$ & \\
ER+ N (\%) & $31(49.2 \%)$ & $65(46.8 \%)$ & 0.375 \\
ER- N (\%) & $32(50.8 \%)$ & $74(53.2 \%)$ & \\
PR+ N (\%) & $25(39.7 \%)$ & $46(33.0 \%)$ & 0.185 \\
PR- N (\%) & $38(27.3 \%)$ & $93(67.0 \%)$ & \\
HER2+ N (\%) & $14(22.2 \%)$ & $27(19.5 \%)$ & 0.323 \\
HER2- N (\%) & $49(77.8 \%)$ & $112(80.5 \%)$ & \\
\end{tabular}

LN: Lymph node; N: number; ER: oestrogen receptor; PR: progesterone receptor; HER2: human epidermal growth factor receptor 2.

on breast cancers reported incidences of p16 positivity of 21 to $51 \%(15,16)$, which is comparable to our result. Slight differences between different immunohistochemistry studies may exist due to usage of different antibodies, laboratory procedures, and grading standards.

The present study found that 16 expression correlated with tumour grade and lymph node metastasis $(p=0.011$, $p=0.003$ ), but not with other demographic and clinical features. This finding is in agreement with previous studies, which found associations between strong p16 expression and various features of breast cancer, such as high grade and lymph node metastasis (17-22).
Table III. Immunohistochemical expression of p16, tumour grades, and age groups.

\begin{tabular}{lccc}
\hline & $\mathrm{p} 16+$ & $\mathrm{p} 16-$ & $p$-Value \\
\hline Tumour grades & & & \\
0 & $1(10.0)$ & $9(90.0)$ & 0.011 \\
I & $7(41.2)$ & $16(58.8)$ & \\
II & $12(17.1)$ & $58(82.9)$ & \\
III & $42(44.2)$ & $53(55.8)$ & \\
Age groups years & & & \\
18-25 & $3(4.8)$ & $7(5.0)$ & 0.693 \\
$26-35$ & $9(14.3)$ & $24(17.3)$ & \\
$36-45$ & $23(36.5)$ & $35(25.2)$ & \\
$46-55$ & $12(19.0)$ & $27(19.4)$ & \\
$56-65$ & $9(14.3)$ & $27(19.4)$ & \\
$\geq 66$ & $7(11.1)$ & $19(13.7)$ & \\
\hline
\end{tabular}

In this study, p16 was not significantly expressed in patients under the age of 55 years with a peak at 36-45 years. This result is in agreement with that of Harbhajanka et al. (23). Our findings are also consistent with the Carolina breast cancer study, where Carey et al. (24) reported that premenopausal African-American women are most likely to present with breast cancer compared to pre-menopausal women.

p16 expression has been shown to increase with age in numerous types of cancers (25-27), but the correlation between p16 expression and age in breast neoplasia has not been well described. Nevertheless, cells in which p16 expression is sustained for prolonged periods of time are known to express proteins that encourage tumour growth $(28,29)$. 
Of the cases examined, $47.5 \%$ were ER-positive, $35.1 \%$ were PR-positive, and $20.3 \%$ were HER2-positive. Furthermore, $52.5 \%$ of cases were ER-negative, $64.8 \%$ were PR-negative, and $79.7 \%$ were HER2-negative. The incidences of ER, PR, and HER2-positive tumours in the Western population are $70 \%$, $54 \%$, and $18.3 \%$, respectively (30). Awadelkarim et al. reported much higher incidence of ER and PR positivity and a lower incidence of HER2 positivity $(64.0 \%, 67.0 \%$, and $17.5 \%$, respectively) in Sudanese patients (31). Furthermore, Sengal et al. reported results that are similar to our results (45\% ER, 38\% PR, and 45.9\% HER2) (32).

The difference in the number of positive cases in Sudan may be due to erroneous staining and the use of diverse antibodies with different specificity and sensitivity. The duration and methods of fixation also differ from one laboratory to another. Furthermore, there may also be genetic differences. Hormone receptors play a significant role in adaptable growth and variation of ordinary breast tissue. They are recognized as prognostic factors, with a positive receptor grade associated with a minor rate of cell proliferation and well differentiated tumours (33).

\section{Limitations}

A limitation of this study was that molecular testing of p16 was not achieved. Consequently, we recommend molecular testing of p16 for future studies to identify mutations and their association with over-expression of this marker.

\section{Conclusion}

In this study, high p16 protein expression was associated with high histologic grade, lymph node metastasis, and poor prognosis. p16 protein expression may be used as a prognostic marker. The reverse relationship between hormone receptors and robust p16 expression might suggest that durable p16 expression is connected to a more aggressive cancer. Nevertheless, larger studies will be essential to validate this finding.

\section{Conflicts of Interest}

The Authors declare that there are no conflicts of interest in relation to this study.

\section{Authors' Contributions}

AH and MS conducted the study designed and laboratory work. EE and MS drafted and revised the manuscript. EE conducted the statistical analyses; all Authors read and approved the final manuscript.

\section{Acknowledgements}

This study was funded by Taif University Researchers Supporting Project number (TURSP2020/157), Taif University Taif, Saudi Arabia.

\section{References}

1 Coleman MP, Quaresma M, Berrino F, Lutz JM, De Angelis R, Capocaccia R, Baili P, Rachet B, Gatta G, Hakulinen T, Micheli A, Sant M, Weir HK, Elwood JM, Tsukuma H, Koifman S, E Silva GA, Francisci S, Santaquilani M, Verdecchia A, Storm HH, Young JL and CONCORD Working Group: Cancer survival in five continents: a worldwide population-based study (CONCORD). Lancet Oncol 9(8): 730-756, 2008. PMID: 18639491. DOI: 10.1016/S1470-2045(08)70179-7

2 Coughlin SS: Epidemiology of breast cancer in women. Adv Exp Med Biol 1152: 9-29, 2019. PMID: 31456177. DOI: 10.1007/978-3-030-20301-6_2

3 Saeed IE, Weng HY, Mohamed KH and Mohammed SI: Cancer incidence in Khartoum, Sudan: first results from the Cancer Registry, 2009-2010. Cancer Med 3(4): 1075-1084, 2014. PMID: 24821265. DOI: $10.1002 / \mathrm{cam} 4.254$

4 Reeder JG and Vogel VG: Breast cancer prevention. Cancer Treat Res 141: 149-164, 2008. PMID: 18274088. DOI: 10.1007/978-0-387-73161-2_10

5 Jara L, Morales S, de Mayo T, Gonzalez-Hormazabal P, Carrasco $\mathrm{V}$ and Godoy R: Mutations in BRCA1, BRCA2 and other breast and ovarian cancer susceptibility genes in Central and South American populations. Biol Res 50(1): 35, 2017. PMID: 28985766. DOI: $10.1186 / \mathrm{s} 40659-017-0139-2$

6 Shin E, Jung WH and Koo JS: Expression of p16 and pRB in invasive breast cancer. Int J Clin Exp Pathol 8(7): 8209-8217, 2015. PMID: 26339389.

7 Shintani S, Mihara M, Nakahara Y, Kiyota A, Yoshihama Y, Ueyama $\mathrm{Y}$ and Matsumura T: Infrequent alternations of $\mathrm{RB}$ pathway (Rb-p16INK4A-cyclinD1) in adenoid cystic carcinoma of salivary glands. Anticancer Res 20(3B): 2169-2175, 2000. PMID: 10928172.

8 Mahajan A: Practical issues in the application of p16 immunohistochemistry in diagnostic pathology. Hum Pathol 51: 64-74, 2016. PMID: 27067784. DOI: 10.1016/j.humpath. 2015.12.021

9 Ciesielska U, Zatonski T, Nowinska K, Ratajczak-Wielgomas K, Grzegrzolka J, Piotrowska A, Olbromski M, Pula B, PodhorskaOkolow M and Dziegiel P: Expression of cell cycle-related proteins p16, p27 and Ki-67 proliferating marker in laryngeal squamous cell carcinomas and in laryngeal papillomas. Anticancer Res 37(5): 2407-2415, 2017. PMID: 28476808. DOI: 10.21873/anticanres. 11580

10 Yang J, Huang XZ, Guo R, Huang Y, Kang AJ, Jin YF, Chen XL and Li ZF: [p16INK4a protein is a specific molecular biomarker of breast cancer]. Nan Fang Yi Ke Da Xue Xue Bao 36(6): 751755, 2016. PMID: 27320873.

11 Kobierzycki C, Grzegrzolka J, Glatzel-Plucinska N, Piotrowska A, Wojnar A, Smolarz B, Romanowicz H and Dziegiel P: Expression of p16 and SATB1 in invasive ductal breast cancer a preliminary study. In Vivo 32(4): 731-736, 2018. PMID: 29936452. DOI: 10.21873/invivo.11301

12 Fischer AH, Jacobson KA, Rose J and Zeller R: Hematoxylin and eosin staining of tissue and cell sections. CSH Protoc 2008: pdb.prot4986, 2008. PMID: 21356829. DOI: 10.1101/pdb. prot 4986

13 Lewis JS Jr, Beadle B, Bishop JA, Chernock RD, Colasacco C, Lacchetti C, Moncur JT, Rocco JW, Schwartz MR, Seethala RR, Thomas NE, Westra WH and Faquin WC: Human papillomavirus 
testing in head and neck carcinomas: Guideline from the College of American Pathologists. Arch Pathol Lab Med 142(5): 559-597, 2018. PMID: 29251996. DOI: 10.5858/arpa.2017-0286-CP

14 Choi EJ, Yun JA, Jeon EK, Won HS, Ko YH and Kim SY: Prognostic significance of RSPO1, WNT1, P16, WT1, and SDC1 expressions in invasive ductal carcinoma of the breast. World J Surg Oncol 11: 314, 2013. PMID: 24373193. DOI: 10.1186/1477-7819-11-314

15 Stefansson OA, Jonasson JG, Olafsdottir K, Bjarnason H, Th Johannsson O, Bodvarsdottir SK, Valgeirsdottir S and Eyfjord JE: Genomic and phenotypic analysis of BRCA2 mutated breast cancers reveals co-occurring changes linked to progression. Breast Cancer Res 13(5): R95, 2011. PMID: 21958427. DOI: 10.1186/bcr3020

16 Bohn OL, Fuertes-Camilo M, Navarro L, Saldivar J and Sanchez-Sosa S: p16INK4a expression in basal-like breast carcinoma. Int J Clin Exp Pathol 3(6): 600-607, 2010. PMID: 20661408.

17 Geradts J, Kratzke RA, Niehans GA and Lincoln CE: Immunohistochemical detection of the cyclin-dependent kinase inhibitor 2/multiple tumor suppressor gene 1 (CDKN2/MTS1) product p16INK4A in archival human solid tumors: correlation with retinoblastoma protein expression. Cancer Res 55(24): 6006-6011, 1995. PMID: 8521382.

18 Herschkowitz JI, He X, Fan C and Perou CM: The functional loss of the retinoblastoma tumour suppressor is a common event in basal-like and luminal B breast carcinomas. Breast Cancer Res 10(5): R75, 2008. PMID: 18782450. DOI: 10.1186/bcr2142

19 Geradts $J$ and Wilson PA: High frequency of aberrant p16(INK4A) expression in human breast cancer. Am J Pathol 149(1): 15-20, 1996. PMID: 8686738.

20 Witkiewicz AK, Rivadeneira DB, Ertel A, Kline J, Hyslop T, Schwartz GF, Fortina $\mathrm{P}$ and Knudsen ES: Association of RB/p16-pathway perturbations with DCIS recurrence: dependence on tumor versus tissue microenvironment. Am J Pathol 179(3): 1171-1178, 2011. PMID: 21756866. DOI: 10.1016/j.ajpath.2011.05.043

21 Karray-Chouayekh S, Baccouche S, Khabir A, SellamiBoudawara T, Daoud J, Frikha M, Jlidi R, Gargouri A and Mokdad-Gargouri R: Prognostic significance of p16INK4a/p53 in Tunisian patients with breast carcinoma. Acta Histochem 113(5): 508-513, 2011. PMID: 20598349. DOI: 10.1016/ j.acthis.2010.05.002

22 Hui R, Macmillan RD, Kenny FS, Musgrove EA, Blamey RW, Nicholson RI, Robertson JF and Sutherland RL: INK4a gene expression and methylation in primary breast cancer: overexpression of p16INK4a messenger RNA is a marker of poor prognosis. Clin Cancer Res 6(7): 2777-2787, 2000. PMID: 10914724.

23 Harbhajanka A, Chahar S, Miskimen K, Silverman P, Harris L, Williams N, Varadan V and Gilmore H: Clinicopathological, immunohistochemical and molecular correlation of neural crest transcription factor SOX10 expression in triple-negative breast carcinoma. Hum Pathol 80: 163-169, 2018. PMID: 29894722. DOI: 10.1016/j.humpath.2018.06.007

24 Carey LA, Perou CM, Livasy CA, Dressler LG, Cowan D, Conway K, Karaca G, Troester MA, Tse CK, Edmiston S, Deming SL, Geradts J, Cheang MC, Nielsen TO, Moorman PG, Earp HS and Millikan RC: Race, breast cancer subtypes, and survival in the Carolina Breast Cancer Study. JAMA 295(21):
2492-2502, 2006. PMID: 16757721. DOI: 10.1001/jama.295. 21.2492

25 Krishnamurthy J, Torrice C, Ramsey MR, Kovalev GI, AlRegaiey K, Su L and Sharpless NE: Ink4a/Arf expression is a biomarker of aging. J Clin Invest 114(9): 1299-1307, 2004. PMID: 15520862. DOI: 10.1172/JCI22475

26 Janzen V, Forkert R, Fleming HE, Saito Y, Waring MT, Dombkowski DM, Cheng T, DePinho RA, Sharpless NE and Scadden DT: Stem-cell ageing modified by the cyclin-dependent kinase inhibitor p16INK4a. Nature 443(7110): 421-426, 2006. PMID: 16957735. DOI: 10.1038/nature05159

27 Ressler S, Bartkova J, Niederegger H, Bartek J, ScharffetterKochanek K, Jansen-Dürr P and Wlaschek M: p16INK4A is a robust in vivo biomarker of cellular aging in human skin. Aging Cell 5(5): 379-389, 2006. PMID: 16911562. DOI: 10.1111/ j.1474-9726.2006.00231.x

28 Coppé JP, Desprez PY, Krtolica A and Campisi J: The senescence-associated secretory phenotype: the dark side of tumor suppression. Annu Rev Pathol 5: 99-118, 2010. PMID: 20078217. DOI: 10.1146/annurev-pathol-121808-102144

29 Coppé JP, Patil CK, Rodier F, Sun Y, Muñoz DP, Goldstein J, Nelson PS, Desprez PY and Campisi J: Senescence-associated secretory phenotypes reveal cell-nonautonomous functions of oncogenic RAS and the p53 tumor suppressor. PLoS Biol 6(12): 2853-2868, 2008. PMID: 19053174. DOI: 10.1371/journal. pbio.0060301

30 Arciero CA, Guo Y, Jiang R, Behera M, O’Regan R, Peng L and Li X: ER+/HER2+ breast cancer has different metastatic patterns and better survival than $\mathrm{ER}^{-} / \mathrm{HER} 2^{+}$breast cancer. Clin Breast Cancer 19(4): 236-245, 2019. PMID: 30846407. DOI: $10.1016 / j . c l b c .2019 .02 .001$

31 Awadelkarim KD, Arizzi C, Elamin EO, Hamad HM, De Blasio P, Mekki SO, Osman I, Biunno I, Elwali NE, Mariani-Costantini $\mathrm{R}$ and Barberis MC: Pathological, clinical and prognostic characteristics of breast cancer in Central Sudan versus Northern Italy: implications for breast cancer in Africa. Histopathology 52(4): 445-456, 2008. PMID: 18315597. DOI: 10.1111/j.13652559.2008.02966.x

32 Sengal AT, Haj-Mukhtar NS, Elhaj AM, Bedri S, Kantelhardt EJ and Mohamedani AA: Immunohistochemistry defined subtypes of breast cancer in 678 Sudanese and Eritrean women; hospitals based case series. BMC Cancer 17(1): 804, 2017. PMID: 29191181. DOI: 10.1186/s12885-017-3805-4

33 Budzik MP, Patera J, Sobol M, Czerw AI, Deptała A and Badowska-Kozakiewicz AM: Clinicopathological characteristics of metaplastic breast cancer - analysis of the basic immunohistochemical profile and comparison with other invasive breast cancer types. Breast 43: 135-141, 2019. PMID: 30553188. DOI: $10.1016 /$ j.breast.2018.12.004 